Egyptian Journal of Aquatic Biology \& Fisheries

Zoology Department, Faculty of Science,

Ain Shams University, Cairo, Egypt.

ISSN 1110 - 6131 Vol. 22(2): 61 - 76 (2018)

ejabf.journals.ekb.eg

\title{
Does feeding African Catfish, Clarias gariepinus vinegar-immersed poultry viscera affect its growth performance, hygienic status and pathogenic bacterial load?
}

\author{
Mohamed M. Toutou ${ }^{* 1}$, Ali A. Soliman', Heba E. Abd Elnabi², Ahmed E. \\ Abouelwafa ${ }^{3}$ and Mohamed M. Abdel Rahim ${ }^{4}$. \\ 1- Fish Nutrition Laboratory, Aquaculture Division, National Institute of Oceanography \\ and Fisheries, Alexandria, Egypt. \\ 2- Fish Resources and Aquaculture Department, Faculty of Environmental Agricultural \\ Sciences, Arish University, Egypt. \\ 3- Microbiology Lab., Marine Environmental Division, National Institute of \\ Oceanography and Fisheries, Alexandria, Egypt. \\ 4- Fish Rearing Lab., Aquaculture Division, National Institute of Oceanography and \\ Fisheries (NIOF), Alexandria, Egypt. \\ Corresponding author: mtoutou50t@yahoo.com
}

\section{ARTICLE INFO}

\section{Article History:}

Received: March12, 2018

Accepted: May 25, 2018

Available online: June 2018

\section{Keywords:}

Catfish

Clarias gariepinus

Poultry Viscera

Ammonia

Growth performance

Serum constituents

Bacterial load

\section{ABSTRACT}

This study was conducted to investigate the effects of replacing commercial feed with vinegar-immersed poultry viscera on growth performance, physiological status and bacterial load of the catfish, Clarias gariepinus. Fish were fed on a commercial diet (T1), poultry viscera (T2) and poultry viscera immersed in commercial vinegar (T3). Catfish with an average body weight of $520 \mathrm{~g}$ were stocked in circular fiberglass tanks each of $2 \mathrm{~m}^{3}$ water volume for 98 days. Water quality parameters, growth performance, feed utilization, flesh composition, serum analysis and bacterial load of feed, water and fish, were measured. Ammonia content in rearing water decreased significantly in $\mathrm{T} 3$ compared to $\mathrm{T} 2$. There were not any significant differences detected $(\mathrm{P}>0.05)$ in survival and growth performance, while significant $(\mathrm{P} \leq 0.05)$ differences in feed utilization and wholebody composition were detected among treatments. The quality indices of fish in terms of flesh composition were in favor of T3. A decrease in the serum's total protein and albumin and an increase in the serum's globulin and cholesterol levels were observed when fish was fed on poultry viscera only. Pathogenic bacterial load in feed, rearing water and fish intestine were at their lowest limit in T3. This study shows that $C$. gariepinus can feed on poultry viscera immersed in commercial vinegar as an alternative feedstuff source to commercial high-priced feed. The ecological impacts of treating environmentally hazardous by-products, like poultry viscera and converting it to a high value by-product are a matter of interest for both aquaculurists and environmentalists alike. More research work is needed to take advantage of the current results in a commercially applicable scale.

\section{INTRODUCTION}

African Catfish are famous to be omnivorous in their food habits (Anyanwu et al.,

2012).They are also strong and tolerant to variety range of stressful environmental conditions (Nwani et al., 2015). They are greatly cultivated in freshwater farms because of their ease in reproduction, high growth performance, tolerance to high density culture conditions, resistance to diseases, good flesh quality and capability to usage a vast diversity of feed (Nyina-wamwiza et al., 2007; Khan and Abidi, 2011; Chor et al., 2013). 
Egyptians dating back to ancient times, Catfish are considered one of the most favorite fish types. Many images of Catfish appeared on the walls of ancient Pharaonic temples. In 2015, the total catfish production in Egypt was 37,914 tons/year, of which 7,455 tons/year were obtained from aquaculture (GAFRD, 2015). African Catfish require about $40 \% \mathrm{CP}$ in their diet and the best results have been achieved through crude protein value ranging from 35 to $50 \%$ for all African Catfish species (Adebayo and Quadri, 2005).

Nutrition is mean of the most critical factors in fish culture for it contributes with more than 50\% of fish production cost (Omoruwou and Edema, 2011). Feeding is one of the major limitations facing aquaculture. The importance of fish meals in the production of animal feeds cannot be conflicted, but forms the major cost and therefore raises the price of the aquafeed exponentially (Olaniyi and Salau, 2013). The feeding can be harmful to the fish's health and may cause a remarkable drop in water quality, reduce growth, decrease feed utilization and increase susceptibility to infection (Priestley et al., 2006). Therefore, there is the need to balance between rapid fish growth and the optimum use of the supplemented feed in order to be economically viable and for the fish to be in good health (Wuraola1 and Omodara, 2014).

Many indigenously raw materials fundamentally poultry by-product meals, blood meals, different oil cakes, cereal by-products, leaf meals, etc... are available in most countries (Akand et al., 1991). These raw materials can be used in formulating supplemental feed for rearing and culturing of various fish species (Bhadra et al., 1997). Compared to plant-based proteins, poultry viscera are easily available throughout the year at a very low price. They are also high in proteins and low in carbohydrates. They have a balanced amino acids profile, are high in digestible feedstuff and lack anti-nutritional factors (Goda et al., 2007; Bhaskar et al., 2015). Hence, chicken viscera are considered a probable substitute for fish meals in diets for a number of fish species (Gupta et al., 2013; Bhaskar et al., 2015).

Poultry by-product meals have been investigated in a numerous extent of aquatic organisms, including common carp, Cyprinus carpio (Paixao and Filho, 1989), grass carp, Ctenopharyngodon idella (Tabinda and Butt, 2012), Nile Tilapia, Oreochromis niloticus (ElHusseiny et al., 2006; Metwalli, 2008; Yones and Metwalli, 2016), catfish, Pangasianodon hypophthalmus (HAO and YU, 2003), African Catfish, Clarias gariepinus (Abdel-Warith et al., 2001), and European Seabass, Dicentrarchus labrax (Srour et al., 2016). Worldwide, poultry viscera are being used in many catfish farms instead of commercial feed which may cause exposure to many fungal and bacterial diseases. More than 500,000 tons of poultry byproducts are available yearly in Egypt (MALR, 2015). These large amounts of poultry byproduct meals are causing some dangerous environmental impacts, such as hosts for vermin, insects, bacteria, and viruses, which may cause in water infection (as a result of nutrient filtration and pathogenic microorganisms) and air pollution, harmful gases and nuisance odorants (FAO, 2011). However, disease which is caused by pathogenic bacteria is a major hindrance for aquaculture production (Romero et al., 2012).

Vinegar has antimicrobial characteristics which makes it beneficial for variety of applications (Rutala et al. 2000; Dohar 2003). For preventing the growth of foodborne pathogenic microorganisms in food, consumers prefer natural preservative methods (Rauha and et al. 2000). To our knowledge, there hasn't been any previous data concerning the treatment of poultry by-products using vinegar. Therefore, this study aims to assess the effects of feeding catfish $C$. gariepinus poultry viscera immersed in commercial vinegar on water quality, growth performance, feed utilization, flesh composition, serum constituents and pathogenic microbial load in both water and fish, and then compare them to the effects that had resulted from those fed on untreated poultry viscera and commercial feed.

\section{MATERIALS AND METHODS}

\section{Experimental Design}

This study was conducted at the Fish Nutrition Laboratory, Baltim Research Station, National Institute of Oceanography and Fisheries (NIOF), Egypt. A total of 180 adult catfish 
C. gariepinus with an average weight of $520 \pm 25 \mathrm{~g} /$ fish were acclimatized to experimental conditions for seven days in concrete tanks $(5 \times 10 \times 1 \mathrm{~m})$. Experimental fish were obtained from a private farm at Kafr El-Sheikh Governorate, Egypt. Nine circular fiberglass tanks and two- $\mathrm{m}^{3}$ water volume were used for stocking the experimental catfish. The tanks were filled with de-chlorinated tap water. After acclimatization, twenty randomly selected fish were stocked in each tank for 14 weeks (98 days). The feed ration was adjusted once every 10 days, based on fish biomass. The water exchange was $20 \%$ daily. Also, the accumulated waste materials were removed every day. Fish were fed twice a day at 09:00 and 15:00 at 5\% body weight for the commercial diet group and $20 \%$ of poultry viscera and poultry viscera immersed in commercial vinegar groups. The total feeds consumed in each tank were recorded and the feed consumed by each fish was calculated accordingly.

\section{Feed Preparation}

Three experimental diets were formulated as, treatment 1: (T1) fish were fed a commercial diet containing 30.5\% crude protein, treatment 2 (T2): fish were fed fresh poultry viscera only, and treatment 3 (T3): fish were fed fresh poultry viscera immersed in commercial vinegar only. The experimental diets were carried out with three replicates each. Fresh poultry viscera were collected freshly from poultry shops every day. Fresh poultry viscera were cut to small pieces each of $3 \mathrm{~cm}$ to fit the fish feeding in T2. In T3, onekilogram of poultry viscera was immersed in one-liter of commercial sugarcane vinegar ${ }^{\circledR}$ (5\%) (weight/volume) for 1 day to avoid bacterial or fungal pathogens before being used. Chemical compositions of these diets are shown in Table (1).

Table 1: Chemical compositions of the experimental diet and poultry viscera as dry matter basis.

\begin{tabular}{|c|c|c|c|}
\hline Ingredients & $\mathrm{T} 1^{\mathrm{I}}$ & T2 & T3 \\
\hline Dry matter (DM) & 93.5 & 35.5 & 36.7 \\
\hline Crud protein $(\mathrm{CP})$ & 30.5 & 34.3 & 34.8 \\
\hline Ether extract & 9.0 & 32.8 & 31.6 \\
\hline Crude fibre & 6.2 & 2.2 & 2.1 \\
\hline Ash & 8.5 & 6.0 & 6.0 \\
\hline Nitrogen free extract (NFE) $)^{2}$ & 45.8 & 24.7 & 25.5 \\
\hline Gross energy $(\mathrm{MJ} / \mathrm{kg} \mathrm{DM})^{3}$ & 18.8 & 25.3 & 25.1 \\
\hline
\end{tabular}

${ }^{1}$ Each kilogram of feeding pellets contains fish meal (5\%), corn gluten (7\%), soybean meal (30\%), yellow corn (10\%), rice bran $(19 \%)$, wheat bran $(25 \%)$, soya oil $(3 \%)$, dicalcium phosphate $(0.7)$ and premix $(0.3 \%)$. Each kilogram of premix contain $(\mathrm{mg}$ $/ \mathrm{kg}$ ): p-amino benzoic acid (9.48), D-biotin (0.38), inositol (379.20), niacin (37.92); Ca-pantothenate (56.88), pyridoxine- $\mathrm{HCl}$ (11.38), riboflavin (7.58), thiamine- $\mathrm{HCl}$ (3.79), L-ascorbyl-2-phosphate Mg (APM) (296.00), folic acid (0.76), cyanocobalamin (0.08), menadione (3.80), vitamin A-palmitate (17.85), a-tocopherol (18.96), calciferol (1.14), $\mathrm{K}_{2} \mathrm{PO}_{4}(2.011), \mathrm{Ca}_{3}\left(\mathrm{PO}_{4}\right)_{2}(2.736)$, $\mathrm{Mg} \mathrm{SO}_{4} 7 \mathrm{H}_{2} \mathrm{O}(3.058)$ and $\mathrm{NaH}_{2} \mathrm{PO}_{4} 2 \mathrm{H}_{2} \mathrm{O}(0.795)$.

${ }^{2}$ Nitrogen free extract $(\mathrm{NFE})=100-[$ Ash $\%+$ lipid $\%+$ protein $\%+$ Fiber $\%]$.

${ }^{3} \mathrm{GE}(\mathrm{MJ} / \mathrm{kg} \mathrm{DM})=($ protein content $\times 23.6)+($ Lipid content $\times 39.5)+$ carbohydrate content $\left.\times 17.2\right)(\mathrm{NRC}, 1993)$.

\section{Water quality parameters}

Water quality parameters (temperature, $\mathrm{pH}$, dissolved oxygen and ammonia) were measured once a week according to the standard method described in APHA (1998).

\section{Growth performance and feed utilization}

Growth performance and feed utilization were evaluated as, gained weight $(\mathrm{GW})=$ $[(\mathrm{fw}-\mathrm{iw}) / \mathrm{iw}]$, specific growth rate $\left(\mathrm{SGR} \% \mathrm{day}^{-1}\right)=100 \times[\ln (\mathrm{fw})-\ln (\mathrm{iw})] \mathrm{t}^{-1}$, feed conversion ratio $(\mathrm{FCR})=\mathrm{FI}-\mathrm{GW}$, protein efficiency ratio $(\mathrm{PER})=(\mathrm{GW}-\mathrm{FI})$, protein productive value $(\mathrm{PPV})=100(\mathrm{PI} / \mathrm{PF})$ and energy utilization $(\mathrm{EU} \%)=100$ (E.g./ EI). Where iw and $\mathrm{fw}=$ mean initial and final body weight $(\mathrm{g})$, respectively, $\mathrm{t}$ is the duration of the experiment (98 days), FI is the total feed intake (g), PI is protein intake (g), PF is protein fed $(\mathrm{g}), \mathrm{EG}$ is the energy gained $(\mathrm{Kcal} / 100 \mathrm{~g})$ and $\mathrm{EI}$ is energy intake (Kcal/100 g).

\section{Biometric parameters}

At the end of the experiments, the general viscera, liver and gut were taken from each experimental fish for biometric parameters. Visceral somatic indexes (VSI), hepatosomatic index (HSI) and relative gut length (RGL) were calculated as the following equation: VSI=visceral weight $(\mathrm{g}) /$ fish weight $(\mathrm{g})$, HSI=liver weight $(\mathrm{g}) /$ fish weight $(\mathrm{g})$ and $\mathrm{RG}$ $\mathrm{L}=$ absolute gut length $(\mathrm{cm}) /$ total body length $(\mathrm{cm})$. Condition factor $(\mathrm{K} \%)=\left(\mathrm{FW} / \mathrm{FL}^{3}\right) \times 100$, 
where $\mathrm{FW}=$ final weight $(\mathrm{g})$ and $\mathrm{FL}=$ final length $(\mathrm{cm})$. Survival rate $(\%)=($ No. of fish at the end of the experiments/No. of fish at the start of the experiments) $\times 100$.

\section{Chemical analysis of diets and whole-body composition}

Chemical analysis of the experimental diets and flesh composition of catfish $C$. gariepinus were performed. Fifteen fish per treatment were scaled, headed and cut from the back. The viscera of each fish were removed. The flesh was then passed rapidly through a meat chopper for several times and mixed thoroughly after each turn to estimate dry matter $(\mathrm{DM})$, crude protein $(\mathrm{CP})$, ether extract $(\mathrm{EE})$, crude fiber $(\mathrm{CF})$ and ash content according to AOAC (2000).

\section{Blood collection and biochemical measurements}

The blood was collected from the caudal vessels and the blood samples were taken in dry clean centrifuge tubes. Serum was separated at $3000 \mathrm{rpm}$ for 15 minutes using a centrifuge and kept in well stoppered plastic vials at $-20{ }^{\circ} \mathrm{C}$ until analysis. Serum total protein and albumin were determined according to the method of Doumas (1975), urea enzymatic was measured according to Patton and Crouch (1977). Serum cholesterol was determined according to the method of Allain et al. (1974). The triglycerides were assessed by the Fossati three-step enzymatic reaction with a Trinder endpoint (Fossati and Prencipe, 1982). Serum lipase was determined by the enzymatic colorimetric assay according to Panteghini et al. (1991). Amylase was determined by the method of Winn-Deen et al. (1988).

\section{Bacterial load}

Preparation of samples: treatment feeds, water and fish gut were removed from fresh specimens then put in a saline solution and homogenized vigorously according to (Al-Harbi, 2010). According to (PHE, 2014), total bacterial count (TBC) was calculated as follows; $1 \mathrm{ml}$ of each sample diluted in $99 \mathrm{ml}$ saline then $1 \mathrm{ml}$ of this dilution was cultured using pour plate technique on nutrient agar plate medium and incubated at $30^{\circ} \mathrm{C}$ for $18-24$ hours. The counts were calculated as CFU $/ 100 \mathrm{ml}$. Bacterial evaluation was performed by the membrane filtration technique according to ISO 9308/1(1990 b) and 7899/2 (1984). One ml of each diluted sample was filtered through $0.45 \mu \mathrm{m}$ pore with a diameter of $47 \mathrm{~mm}$, and a grid of sterile cellulose membrane. For fecal streptococci, membranes were placed onto the surface of Slanetz and Bartley medium after 72 hours of incubation at $37^{\circ} \mathrm{C}$. The dark red colonies were counted for the detection of Vibrio spp. The membranes were placed onto the surface of TCBS (Thiosulphate citrate bile salt sucrose) agar and incubated at $37^{\circ} \mathrm{C}$ for 24 hours. Large green and /or yellow colonies were considered to be Vibrio spp. Bismuth Sulphite Agar Medium and SS-agar were used in the detection and enumerations of Salmonella spp. after incubation at $35-37^{\circ} \mathrm{C}$ for $18-24$ hours, the black colony was counted. Aeromonas Isolation Medium Base was used for the detection of Aeromonas sp. After incubation at $35-37^{\circ} \mathrm{C}$ for 18-24 hours, the dark green, opaque with dark center colony was counted. For the detection and counting of the Staphylococcus aureus, membranes were placed onto the surface of Mannitol Salt agar and incubated at $35^{\circ} \mathrm{C}$ for $18-24$ hours, yellow colonies were counted. For the detection and counting of the Pseudomonas sp, membranes were placed onto the surface of Pseudomonas isolation agar blue-green colonies and observed after incubation for 40-48 hours at $35^{\circ} \mathrm{C}$.

\section{Statistical analysis}

The statistical analysis of the obtained data was done by SPSS computer software package, version 20 for one-way ANOVA according to Levesque (2007). Means were statistically compared for the significance $(P \leq 0.05)$ using multiple range test SPSS 20.

\section{RESULTS AND DISCUSSION}

Table 2 shows the water quality data. Non-significant differences were observed in temperature and $\mathrm{pH}$ among treatments during the experimental period. However, values of ammonia, nitrite and dissolved oxygen exhibited significant differences. Water temperature ranged from 20.0 to $22.5 \pm 1.0^{\circ} \mathrm{C}$. Water $\mathrm{pH}$ w a s 
(7.42 \pm 0.03 ), salinity was $0.9 \pm 0.2 \mathrm{ppt}, \mathrm{NO}_{2}-\mathrm{N}$ was $0.19 \pm 0.01$ for $\mathrm{T} 1$, while $0.26 \pm 0.04$ was for T2 and $0.22 \pm 0.03 \mathrm{mg} / \mathrm{L}$ for $\mathrm{T} 3$.

Dissolved oxygen varied from $7.0 \pm 0.4,6.1 \pm 0.5,6.5 \pm 0.3 \mathrm{mg} / \mathrm{L}$ for $\mathrm{T} 1, \mathrm{~T} 2$ and T3, respectively. Total content of ammonia exhibited higher significant $(\mathrm{P} \leq 0.05)$ values in T2 $(0.516 \mathrm{ppm})$ compared with moderate values in T1 $(0.406 \mathrm{ppm})$ and the lowest values in T3 (0.370ppm) without significant differences between T1 and T3.

Table 2 : Water quality parameters during the experimental period.

\begin{tabular}{|l|c|c|c|}
\hline Water quality & $\mathrm{T} 1$ & $\mathrm{~T} 2$ & $\mathrm{~T} 3$ \\
\hline Temperature $(\mathrm{C})$ & $22.2 \pm 0.6$ & $22.7 \pm 0.5$ & $22.8 \pm 0.7$ \\
\hline $\mathrm{pH}$ & $7.363 \pm 0.01^{\mathrm{b}}$ & $7.497 \pm 0.01^{\mathrm{a}}$ & $7.40 \pm 0.02^{\mathrm{b}}$ \\
\hline $\mathrm{DO}_{2}(\mathrm{ppm})$ & $7.0 \pm 0.4^{\mathrm{a}}$ & $6.1 \pm 0.5^{\mathrm{b}}$ & $6.5 \pm 0.3^{\mathrm{ab}}$ \\
\hline $\mathrm{NH}_{3}(\mathrm{ppm})$ & $0.399 \pm 0.015^{\mathrm{b}}$ & $0.512 \pm 0.012^{\mathrm{a}}$ & $0.347 \pm 0.012^{\mathrm{c}}$ \\
\hline $\mathrm{NO}_{2}-\mathrm{N}(\mathrm{ppm})$ & $0.19 \pm 0.01^{\mathrm{b}}$ & $0.26 \pm 0.04^{\mathrm{a}}$ & $0.22 \pm 0.03^{\mathrm{ab}}$ \\
\hline
\end{tabular}

Growth performance, survival ratio and feed utilization of catfish $C$. gariepinus reared under different feeding regimes are presented in Table (3). The results indicated that there weren't any significant differences in the final body weight, gain, specific growth rate and survival rate among treatments. Data of feed utilization parameters showed significant differences among treatments $(P \leq 0.05)$. The highest feed intake value was observed in T2 followed by T3 and T1, respectively. PER showed higher but non-significant differences between poultry viscera by-product treatments and commercial diet. The same trend with significant differences $(P \leq$ 0.05 ) was observed in protein productive values where the lowest value was observed in T1 and the highest value was in T3. Better utilization of energy was detected in favor of T1, where the highest value was in T1 and the lowest value was obtained in $\mathrm{T} 2$.

Table 3: Growth parameters, survival and feed utilization during the experimental period.

\begin{tabular}{|c|c|c|c|}
\hline Treatments $^{*}$ & T1 & T2 & T3 \\
\hline IW (g/fish) & $516.7 \pm 12.3$ & $530.0 \pm 9.5$ & $535.0 \pm 10.6$ \\
\hline FW (g/fish) & $772.7 \pm 34.9$ & $741.0 \pm 36.4$ & $766.3 \pm 14.3$ \\
\hline GW (g/fish) & $256.0 \pm 34.2$ & $211.0 \pm 31.1$ & $231.3 \pm 40.1$ \\
\hline SGR(\%/day) & $5.6 \pm 0.13$ & $5.4 \pm 0.16$ & $5.5 \pm 0.07$ \\
\hline Survival rate \% & $98.89 \pm 1.11$ & $94.44 \pm 1.93$ & $94.44 \pm 2.94$ \\
\hline FI (g/fish) & $576 \pm 67.7^{\mathrm{b}}$ & $1600 \pm 57.7^{\mathrm{a}}$ & $1416 \pm 44.1^{\mathrm{a}}$ \\
\hline FCR & $2.0 \pm 0.1^{\mathrm{b}}$ & $2.8 \pm 0.5^{\mathrm{a}}$ & $2.3 \pm 0.1^{\mathrm{a}}$ \\
\hline PER & $1.49 \pm 0.02$ & $2.17 \pm 0.41$ & $2.39 \pm 0.18$ \\
\hline PPV & $5.9 \pm 0.5^{\mathrm{b}}$ & $8.2 \pm 1.4^{\mathrm{b}}$ & $14.6 \pm 1.1^{\mathrm{a}}$ \\
\hline EU & $23.9 \pm 2.3^{\mathrm{a}}$ & $10.5 \pm 1.4^{\mathrm{b}}$ & $15.0 \pm 1.5^{\mathrm{b}}$ \\
\hline
\end{tabular}

*Means followed by the same letters are not significant, but different letters are significant $(P<0.05)$.

Data in Table 4 present values of hepatosomatic index (HSI), visceral-somatic index (VSI), relative gut length (RGL), condition factor (K) and $\mathrm{pH}$ of intestine, stomach, fish flesh and the whole body. Values of biometric parameters showed significant differences $(P \leq$ $0.05)$ among treatments. Visceral-somatic index was significantly different $(P \leq 0.05)$, where the lowest value was recorded in T2 group and the highest one was recorded in T3. The minimum values of HSI, RGL and $\mathrm{K}$ were recorded in T3 treatments. Results showed that there weren't any significant differences of $\mathrm{pH}$ values in intestine, stomach, and fish flesh, while a significant $(\mathrm{P} \leq 0.05)$ difference among treatments in the whole body was detected with the highest value in $\mathrm{T} 2$. 
Table 4: Biometric parameters and $\mathrm{pH}$ values of fish at the end of the experiment.

\begin{tabular}{|c|c|c|c|c|}
\hline \multicolumn{2}{|c|}{ Treatment" } & $\mathrm{T} 1$ & $\mathrm{~T} 2$ & T3 \\
\hline \multicolumn{2}{|r|}{ VSI } & $5.8 \pm 1.00^{\mathrm{b}}$ & $4.8 \pm 0.12^{b}$ & $6.8 \pm 0.95^{\mathrm{a}}$ \\
\hline \multicolumn{2}{|r|}{ HSI } & $1.2 \pm 0.01^{\mathrm{a}}$ & $1.2 \pm 0.06^{\mathrm{a}}$ & $1.0 \pm 0.07^{b}$ \\
\hline \multicolumn{2}{|r|}{ RGL } & $2.15 \pm 0.01^{b}$ & $2.45 \pm 0.06^{\mathrm{a}}$ & $2.05 \pm 0.07^{\mathrm{b}}$ \\
\hline \multicolumn{2}{|c|}{ Condition factor $(\mathrm{K})$} & $0.9 \pm 0.04^{\mathrm{a}}$ & $0.9 \pm 0.03^{\mathrm{a}}$ & $0.8 \pm 0.05^{b}$ \\
\hline \multirow[t]{4}{*}{$\mathrm{pH}$} & Intestine & $6.52 \pm 0.48$ & $6.75 \pm 0.45$ & $6.59 \pm 0.51$ \\
\hline & Stomach & $6.47 \pm 0.53$ & $6.53 \pm 0.58$ & $6.60 \pm 0.60$ \\
\hline & Flesh & $6.5 \pm 0.40$ & $6.57 \pm 0.43$ & $6.46 \pm 0.45$ \\
\hline & Whole body & $6.03 \pm 0.01^{b}$ & $6.15 \pm 0.03^{\mathrm{a}}$ & $6.08 \pm 0.01^{\text {ab }}$ \\
\hline
\end{tabular}

* Means followed by the same letters are not significant, but different letters are significant $(P<0.05)$.

The flesh composition of the experimental fish as presented in Table 5 shows that there were significant variations $(P \leq 0.05)$ in the moisture, crude protein, ether extract and ash content levels of the fish fed on different experimental diets. However, the moisture and ash were lower in T3; whereas crude protein was lower in $\mathrm{T} 2$ treatment. On the other hand, moisture and ash were significantly higher in T2 than in the other treatments. Crude protein value was the highest in T3 and ether extract was the highest $\mathrm{T} 1$ group.

Table 5: Flesh composition of fish at the end of the experiment.

\begin{tabular}{|c|c|c|c|c|}
\hline Treatments $^{*}$ & Initial samples & T1 & T2 & T3 \\
\hline Moisture & $78.31 \pm 0.45$ & $73.95 \pm 0.45^{\mathrm{b}}$ & $77.6 \pm 0.90^{\mathrm{a}}$ & $72.80 \pm 0.60^{\mathrm{b}}$ \\
\hline Crude protein & $16.13 \pm 0.62$ & $19.7 \pm 0.62^{\mathrm{b}}$ & $16.4 \pm 0.58^{\mathrm{c}}$ & $21.7 \pm 0.24^{\mathrm{a}}$ \\
\hline Ether extract & $1.38 \pm 0.15$ & $2.75 \pm 0.15^{\mathrm{a}}$ & $2.0 \pm 0.10^{\mathrm{b}}$ & $2.05 \pm 0.05^{\mathrm{b}}$ \\
\hline Ash & $4.14 \pm 0.01$ & $3.53 \pm 0.01^{\mathrm{b}}$ & $4.36 \pm 0.06^{\mathrm{a}}$ & $3.33 \pm 0.02^{\mathrm{c}}$ \\
\hline
\end{tabular}

*Means followed by the same letters are not significant, but different letters are significant $(P<0.05)$.

Means of total protein $\left(\mathrm{g} \mathrm{dL}^{-1}\right)$ and globulin $\left(\mathrm{g} \mathrm{dL}^{-1}\right)$ indicated a significant difference $(P \leq 0.05)$ between treatments, with the minimum values recorded for $\mathrm{T} 2$ and the maximum for T1 treatment (Table 6). Results of serum albumin $\left(\mathrm{g} \mathrm{dL}^{-1}\right)$ and $\mathrm{A} / \mathrm{G}$ indicated a significant difference $(P \leq 0.05)$ between treatments, with the minimum values recorded for T3 treatment and the maximum values for T1 treatment. Means of serum cholesterol $\left(\mathrm{mg} \mathrm{dL}^{-1}\right)$, triglycerides $\left(\mathrm{mg} \mathrm{dL}^{-1}\right)$ and lipase (U/l) indicated that there is a significant difference $(P \leq 0.05)$ between treatments. The lowest values of these parameters were observed in T2 but the highest values were observed in T3 treatment. Data analysis of serum urea $\left(\mathrm{mg} \mathrm{dL}^{-1}\right)$ and lipase (U/l) indicated that the lowest values were observed in T2 and T3 treatments and the highest values were recorded for T1 treatment.

Table 6: Blood biochemical parameters at end of experimental period

\begin{tabular}{|c|c|c|c|}
\hline Treatments & $\mathrm{T} 1$ & $\mathrm{~T} 2$ & $\mathrm{~T} 3$ \\
\hline Total Protein $\left(\mathrm{g} \mathrm{dL}^{-1}\right)$ & $3.9 \pm 0.18^{\mathrm{a}}$ & $2.5 \pm 0.12^{\mathrm{b}}$ & $3.5 \pm 0.12^{\mathrm{a}}$ \\
\hline Albumin $\left(\mathrm{g} \mathrm{dL}^{-1}\right)$ & $1.6 \pm 0.12^{\mathrm{a}}$ & $1.4 \pm 0.06^{\mathrm{b}}$ & $1.2 \pm 0.06^{\mathrm{b}}$ \\
\hline Globulin $\left(\mathrm{g} \mathrm{dL}^{-1}\right)$ & $2.3 \pm 0.06^{\mathrm{a}}$ & $1.9 \pm 0.06^{\mathrm{b}}$ & $2.3 \pm 0.07^{\mathrm{a}}$ \\
\hline $\mathrm{A} / \mathrm{G}$ & $0.7 \pm 0.04^{\mathrm{b}}$ & $0.8 \pm 0.01^{\mathrm{a}}$ & $0.5 \pm 0.01^{\mathrm{c}}$ \\
\hline Cholesterol $\left(\mathrm{mg} \mathrm{dL}^{-1}\right)$ & $158.7 \pm 2.6^{\mathrm{b}}$ & $150.0 \pm 2.6^{\mathrm{c}}$ & $190.0 \pm 4.6^{\mathrm{a}}$ \\
\hline Triglyceride $\left(\mathrm{mg} \mathrm{dL}^{-1}\right)$ & $108.0 \pm 1.8^{\mathrm{b}}$ & $88.1 \pm 1.9^{\mathrm{c}}$ & $255.3 \pm 5.5^{\mathrm{a}}$ \\
\hline Urea $\left(\mathrm{mg} \mathrm{dL}^{-1}\right)$ & $14.3 \pm 0.88^{\mathrm{a}}$ & $12.0 \pm 0.58^{\mathrm{b}}$ & $11.0 \pm 0.58^{\mathrm{b}}$ \\
\hline Lipase $(\mathrm{U} / \mathrm{l})$ & $7.3 \pm 0.23^{\mathrm{b}}$ & $7.0 \pm 0.12^{\mathrm{b}}$ & $14.5 \pm 0.48^{\mathrm{a}}$ \\
\hline Amylase $(\mathrm{U} / \mathrm{l})$ & $1.9 \pm 0.12^{\mathrm{a}}$ & $1.2 \pm 0.06^{\mathrm{b}}$ & $1.3 \pm 0.09^{\mathrm{b}}$ \\
\hline
\end{tabular}

*Values with different superscript are significantly different $(P<0.05)$. 
Table 7: Bacterial load count composition recovered from samples of treatment feed, water and intestine of Clarias gariepinus at end of experimental period.

\begin{tabular}{|c|c|c|c|c|c|c|c|c|c|}
\hline \multirow{2}{*}{ Treatments } & \multicolumn{3}{|c|}{ Treatments feed } & \multicolumn{3}{|c|}{ Water } & \multicolumn{3}{c|}{ Intestine of fish } \\
\cline { 2 - 10 } & T1 & T2 & T3 & T1 & T2 & T3 & T1 & T2 & T3 \\
\hline Total Bacterial Count & 119 & 527 & 17 & 179 & 670 & 80 & 138 & 355 & 37 \\
\hline Shigella sp. & 35 & 147 & Nil & 35 & 154 & 2 & 35 & 110 & 11 \\
\hline Salmonella sp. & 35 & 90 & Nil & 15 & 45 & 2 & Nil & Nil & Nil \\
\hline Enterococcus spp. & 10 & 180 & 8 & Nil & 188 & Nil & Nil & 165 & Nil \\
\hline Vibrio spp & 2 & Nil & Nil & 46 & 89 & Nil & 46 & 4 & Nil \\
\hline Aeromonas sp & 16 & 58 & 7 & 43 & 83 & 6 & 32 & 48 & 14 \\
\hline Staphylococcus aerus & 9 & 36 & Nil & 12 & 85 & Nil & Nil & 17 & Nil \\
\hline
\end{tabular}

\section{DISCUSSION}

The water quality values obtained in this study were not within the acceptable ranges for C. gariepinus according to the studies of Eyo and Olatunde (2000) and Olurin et al. (2006). However, dissolved oxygen, temperature and $\mathrm{pH}$ values were within the recommended levels (Moogouel et al., 2010). Oyewole et al (2008), stated that African Catfish can grow very well in culture water where DO. Frequently decreases below the optimum level $(5 \mathrm{ppm})$. Consumption time, leaching rate, protein content and assimilation of feed are the main factors affecting the content of ammonia and nitrite in fish rearing water (Alabaster and Lloyd, 1980). Lower contents of ammonia and $\mathrm{NO} 2$ in $\mathrm{T} 3$ in the present study reflected quicker and better assimilation of poultry viscera immersed in commercial vinegar in comparison to T2. Also, low feed's attraction and leaching time in T1 reflect the moderate value of ammonia. Generally, ammonia is toxic to fish if allowed to accumulate in fish ponds. Fish cannot efficiently extract energy from feed under toxic levels. If the ammonia gets lethal levels, the fish will become lethargic and eventually fall into a coma and die (Alabaster and Lloyd, 1980; Department of Water Affairs and Forestry, 1996). Values of ammonia obtained in the current study are higher than Ajiboye et al. (2015) and lower than Moogouel et al. (2010), but still within critical limits. At a content of $0.19 \mathrm{mg} \mathrm{NH} 3 / \mathrm{l}$. the growth indices of channel catfish are significantly decreased. Potential sub-lethal effects in temperate fish occur in the level of $0.3-0.8 \mathrm{mg} \mathrm{NH} 3 / \mathrm{l}$. The 96-hour LC50 for African Catfish larvae (C. gariepinus) is $2.30 \mathrm{mg} \mathrm{NH} 3 / 1$ (Alabaster and Lloyd, 1980; Department of Water Affairs and Forestry, 1996). Data obtained in the present study for NO2 were not in the desirable range. Santhosh and Singh (2007) recommended NO2 concentration in water should be under $0.5 \mathrm{mg} \mathrm{L}-1$, while OATA (2008) recommended that it should be less $0.2 \mathrm{mg} \mathrm{L}-1$ in freshwater. Better values of oxygen, ammonia and nitrite were obtained in T3 rather than T2, meaning that treating poultry viscera with commercial vinegar improved environmental conditions.

There weren't any significant differences among treatments for growth performance and most feed utilization parameters. Similar results were reported by Yang et al. (2006) for Carassius auratus gibelio (Hu et al., 2008), C. gariepinus (Goda et al., 2007), Clarias batrachus (Giri et al., 2010; Gupta et al., 2013), grass carp Ctenopharyngodon idella (Tabinda and Butt, 2012), Cirrhinus mirigala (Tabinda et al., 2013), Pelodiscus sinensis (Sun et al., 2014) and Lutjanus guttatus (Hernandez et al., 2014) fed on diets containing graded poultry viscera meals. In this study, poultry viscera contain nearly $35 \%$ crude protein, $32.5 \%$ ether extract and $2.2 \%$ ash, which might be a good for catfish. These results were in agreement with Nyina-Wamwiza et al. (2007) who obtained data. Giri et al. (2000) have showed that dried chicken viscera can be incorporated in up to $30 \%$ of the diet for juveniles of $C$. batrachus without affecting nutrients' digestion and performance. Poultry by-product meals present a beneficial source of dietary protein for fish farming. While, they differ in quality 
between regions and countries, and some sources is shortage in one or more essential amino acids (Davies et al., 1991; Nengas et al., 1999; Yigit et al., 2006). Results of the current work disagreed with Yamamoto et al. (2002) who reported that feed intake and growth performance decreased in C. gariepinus (Abdel-Wareth et al., 2001; Goda et al., 2007), C. batracus (Giri et al., 2000; Hu et al., 2008) and Anabas testudineus (Bhaskar et al., 2015) that had been fed poultry viscera meals in their diets at high inclusion levels.

In the present study, fish fed T2 diet had the highest FCR, which meant that they required $7.583 \mathrm{~kg}$ of poultry viscera to convert to $1 \mathrm{~kg}$ of fish meat. According to Houlihan et al. (2001), FCR should never go above 2 for artificial diets. However, for fresh diets, it depends on the price of feed and the total feed cost per one $\mathrm{kg}$ of produced fish (economic value). The results of feed utilization in our study were in agreement with Sawhney and Gandotra (2010), who reported that feed conversion ratio (FCR) can determine the efficiency of fish and the biological value of protein in feed. The biological value of the protein source relies on its amino acid profile (Massumotu et al. 1996; Sogbesan et al. 2006) as well as its digestion (Jabir et al., 2012). Also, PER values of the present study were not significantly different. This result was in agreement with Nyina-Wamwiza et al. (2007). They obtained PER that was lower than the 2.7 obtained in $C$. batrachus that was fed a diet containing $18 \%$ of chicken viscera meal. The acceptable values of FCR and PER obtained for C. gariepinus fed diets T2 and $\mathrm{T} 3$ compared to $\mathrm{T} 1$, are enabled by the untraditional animal sources of protein that used (poultry viscera) which are fulfill in essential amino acids.

The fish survival rate was not affected by the experimental diets. This result was in agreement with (NRC, 2011) as C. gariepinus is an omnivorous aquatic fish that efficiently uses animal protein sources to meet energy requirements. Additionally, these results demonstrate that the protein quality of poultry viscera was well accepted by the fish. Survival rate during the experiment was greater than $92 \%$, indicating that fish has grown in good experimental conditions. This result was in agreement with Oke et al. (2016). Also, Rawles et al. (2009), didn't find any significant variations in the survival percent between Hybrid Striped Bass, (Morone chrysops $\times$ Morone saxatilis) that was fed on $100 \%$ fish meal diets and after its feed was replaced by diets included with poultry by-product meals at 45, 70, and 100\%. The low and nonsignificant survival rate obtained in the current study may be related to the high content of fat that reached nearly $(32 \%)$ in poultry viscera within the tested diets (T2 and T3) compared with T1 treatment.

There were significant variations among the experimental feeds in VSI, HSI and GRL values. These results are in contrast with the findings of $\mathrm{Hu}$ et al. (2008), and Aydın and Gümüş (2013) and in agreement with the results obtained by Rawles et al. (2006), and Yang et al. (2006). Results of condition factors (K) revealed that treatments fed on poultry viscera kept the condition factor at a high value in T2 and T3. This result disagreed with the findings of Srour et al., (2016). This may be attributed to how previous authors used dried poultry by-products, while in the present study fresh poultry viscera was used. Idodo-Umeh (2005) and Abowei and Hart (2009) stated that the length/weight relationship of fish, as well as recognized a growth index, is a major management tool applied in evaluation the mean weight at a presented length increase. The condition factor in the intensive culture are often less than 1, whereas the values of condition factors under the natural water bodies are higher than those in the intensive culture ponds (Okan and Gamsiza, 2010).

The results of fish's whole-body composition have shown an increase in crude protein values and ether extract over the initial fish samples. The increase in the crude protein of all samples may have been an indicator that the poultry viscera used had a positive effect on the fish. It shows that the experimental fish effectively converted and 
utilized the protein from the experimental diets into their bodies' protein. These findings are in agreement with the work of Orire (2010). However, ether extract content had increased; this may have been probably caused by high fat in poultry viscera. The increased body fat content may have been due to the increased energy of poultry viscera diets, which have greater fat contents (Table 1). These results were in agreement with Goda et al. (2007), Giri et al. (2010) and Sugumaran and Radhakrishnan (2015). These authors reported that replacing fish meal with poultry viscera meal in fish diets increases the whole body's lipid content of fish. The ash content decreased in fish groups that were fed poultry viscera in the diets, and this is in agreement with the observation of Giri et al. (2010) and Sugumaran and Radhakrishnan (2015) in C. batrachus juveniles and African Catfish C. gariepinus, respectively.

There were significant differences in all serum biochemical parameters in the present study. Specific serum chemistry could be applied to identify tissue damage (Patti and Kulkarni, 1993). The decrease in serum total protein in T2 and T3 was similar to that observed by Yadav et al. (2003) when fish were fed stem bark extract of Croton tiglium. However, the results reported for serum proteins are in agreement with those obtained by Malla and Bashamohiden (1995). The decrease in the serum's total protein and albumin levels may be attributed to their degradation and also to their possible use in metabolic purposes. The results were in agreement with those of Bradbury et al. (1987), who noted that reduced protein content and albumin might also be attributed to the destruction or necrosis of cells and the consequent impairment in protein synthesis machinery. The observed reduction in protein in this work indicated that the physiological strategy applied by the fish in order to manage stress was induced by feeding poultry viscera. The demand for more energy so as to adapt to the changed metabolic system possibly stimulates derivative processes, e.g. proteolysis and the utilization of degraded products for raised energy metabolism. Comparable to this study, a notable decrease in serum albumin and total proteins of $O$. niloticus have been reported by El-Sayed and Saad (2007) and on C. gariepinus (Amin and Hashem, 2012).

The increase of cholesterol in T2 and T3 groups indicated an increase in lipid concentration in the blood and retarded of fat metabolism on fish. Our result is in agreement with that reported by Öner et al. (2008) who stated that the concentration of cholesterol may increase because of liver and kidney failure causing the release of cholesterol into the blood of $O$. niloticus. Cholesterol is a building block for cell membranes and for sex hormones like estrogen and testosterone. Around $80 \%$ of the cholesterol is productive by the liver (Hasheesh et al., 2011). The results of the present study were in agreement with El-Sayed and Saad (2007) for O. niloticus, Borges et al. (2007) and O. niloticus Firat et al. (2011). Blood biochemistry parameters that had been determined also fall within the ranges reported for Heterobranchus longifilis and Heteroclarias hybrid (Okorie-Kanu and Unakalamba, 2014 a, b). Significant differences were observed in serum triglyceride of $C$. gariepinus that fed on the commercial diet in T1 when compared to T2 and T3. That might have been due to liver dysfunction according to Kaplan et al. (1988).

In the present study, serum urea levels decreased when fish were fed poultry viscera. This result is in agreement with Kefi et al. (2013) who reported that high concentrations of urea in $O$. andersonii. This is probably to be a sign of stress related with the increase in the cortisol level. Significant differences of lipase and amylase concentrations with different directions were recorded. Increased values of serum lipase in fish may be related to the elevation of the activity of liver lipase, which mediated the mobilization of liver lipid reserves in fish.

The lowest concentration of pathogenic microbe in rearing water, diets and fish meat in T3 attributed to the antibacterial effects of vinegar. In this context, vinegar including the organic acids and mostly acetic acid pass through cell membranes of microorganisms which causing the death of bacterial cell (Bjornsdottir and et al. 2006; 
Chang and Fang 2007). The bacterial strains, temperature, $\mathrm{pH}$, ionic strength and acid concentration affect the antimicrobial activity of organic acids (Cheng and et al 2003). Numerous organic acids are naturally found in several of fermented foods. When the effects of organic acids on killing of transmitted by food pathogenic bacteria were investigated, it was stated that acetic acid was the major lethal to Escherichia coli O157: H7, followed by lactic, citric and malic acids (Ryu and et al. 1999). Numerous studies have investigated that vinegar could be used to prohibit pathogenic bacteria on vegetables and fresh fruits (Wu and others 2000; Rhee and others 2003; Sengun and Karapinar 2004; Chang and Fang 2007). Sengun and Karapinar (2004) showed the effects of vinegar containing (4\% acetic acid) and lemon juice 1:1 (v/v) mixture of lemon juice and vinegar on Salmonella typhimurium when used carrots for several exposure times $(0,15,30$, and 60 minutes). Whereas both vinegar and lemon juice showed that antimicrobial effect on $S$. typhimurium at whole times. The ultimate decrease in S. typhimurium populations happened at 60 minutes of treatment. Chang and Fang (2007) estimated the antimicrobial influence of rice vinegar on lettuce inoculated with E. coli O157: H7. They record a 3-log decreasing that was caused by commercial vinegar treatment that contained $5 \%$ acetic acid for 5 minutes at $25{ }^{\circ} \mathrm{C}$. Otherwise, less than $1 \log$ reduction was observed using $0.5 \%$ acetic acid treatment for 5 minutes. The presence of vibrio in the intestine of $\mathrm{T} 1$ may be attributed to its presence in the feed, in addition to the health condition of fish that enhanced this species of bacteria.

\section{CONCLUSION}

The present study revealed that using poultry viscera immersed in commercial vinegar as a diet for catfish Clarias gariepinus had positive impacts on the growth, feed utilization and whole body's chemical composition. Therefore, it is recommended to use poultry viscera immersed in commercial vinegar, because it might be an effective and economic alternative feedstuff for high priced commercial feed with a slight defect in biochemical and health status of fish. At the same time, the ecological impacts of treating dangerous by-products like poultry viscera and converting them to high value by-products are a matter of interest for both aquaculurists and environmentalists alike. More research work is needed to take advantage of the current results on a commercially applicable scale.

\section{REFERENCES}

Abdel-Warith, A. A.; Russell, P.M. and Davies, S.J. (2001). Inclusion of a commercial poultry by-product meal as a protein replacement of fish meal in practical diets for African catfish Clarias gariepinus (Burchell 1822). Aquacult. Res., 32 (1): 296-305.

Abowei, J.F.N. and Hart, A.I. (2009). Some morphometric parameters of ten species from the Lower Nun River, Niger Delta. Res. J. Bio. Sci., 4(3): 282-288.

Adebayo, O.T. and Quadri, I.C. (2005). Dietary protein level and feeding rate or hybrid clarid catfish, Clarias gariepinus X Eterobranchus bidorsallis in homestead tanks. J. Appl. Aquacult.,17(1):97-106.

Ajiboye, A. O.; Awogbade, A. A. and Babalola, O. A. (2015). Effects of water exchange on water quality parameters, nutrient utilization, and growth of African catfish (Clarias gariepinus). Intern. J. Livestock., 6(5):57-60.

Adeyemi, S.O.; Bankole, N. O.; Adikwu, I.A. and Akombo, P.M. (2009). Age, Growth, and Mortality of some commercially important Fish species in Gbadikere Lake, Kogi State, Nigeria. Int. J. of Lakes and Rivers Res. India Publications, 2(1): 63 - 69.

Akand, A.M.; Soeb, M.; Hasan, M.R. and Kibria, M.G. (1991). Nutritional requirements of Indian major carp, Labeo rohita (Hamilton). Effect of dietary protein on growth, food conversion, and body composition. Agriculture International, 1: 35-43. 
Allain, C.C.; Poon, L.S.; Chan, C.S.; Richmond, W. and Fu, P.C. (1974). Enzymatic determination of total serum cholesterol. Clin Chem., 20(4): 470-475.

Amin, K. A. and Hashem. K. S. (2012). Deltamethrin-induced Oxidative Stress and Biochemical Changes in Tissues and Blood of Catfish (Clarias gariepinus): Antioxidant Defense and Role of Alpha-Tocopherol. BMC Veterinary Research 8: 45.

Anyanwu, D. C.; Umeh, O. I.; Maduka, B. C. and Mbchu, M. U. (2012). Nutrient utilization and growth of catfish (Clarias gariepinus) fed dietary levels of cassava leaf meal. Pak. J. Nutr., 11(11): 1037-1040.

AOAC (2000). Official Methods of Analysis. Association of Official Analytical Chemists. Washington, DC.

APHA (1998). Standard methods for the examination of water and wastewater, 20th edition. American Public Health Association, Washington, D.C.

Alabaster, J.S. and Lloyd, R. (1980). Water Quality Criteria for Freshwater Fish. Chapter 4: Ammonia (p.85-102) in London: Butterworths.

Atamanalp, M. and Yanik, T. (2003). Alterations in Hematological Parameters of Rainbow Trout (Oncorhynchus mykiss) Exposed to Mancozeb. Turkish Journal of Veterinary and Animal Science, 27: 1213-1217.

Aydın, B. and Gümüş, E. (2013). Replacement of fishmeal by poultry by-product meal, supplemented with lysine, methionine, and threonine, in diets for fry of Nile tilapia (Oreochromis niloticus). The Israeli Journal of Aquaculture-Bamidgeh, 65: 1-7.

Bhadra, A.; Hossain, M.A.; Kamal, M. and Ahmed, G.U. (1997). Growth and survival of African catfish (Clarias gariepinus) on formulated feed. Bangladesh Agril. Sci., 24(1): $123-129$.

Bhaskar, P.; Ray, A.K. and Pyne, S.K. (2015). Growth performance study of koi fish, Anabas testudineus (Bloch) by utilization of poultry viscera, as a potential fish feed ingredient, replacing fish meal. International Journal of Recycling Organic Waste in Agriculture, 4: $31-37$.

Borges, A.; Scotti, L.V.; Siqueira, D.R.; Zanini, R., Amaral, F.; Jurinitz, D.F. and Wassermann, G.F. (2007). Changes in hematological and serum biochemical values in jundia' Rhamdia quelen due to sub-lethal toxicity of cypermethrin. Chemosphere, 69: 920-926.

Bradbury, S.P.; Symonic, D.M.; Coats, J.R. and Atchism, G.J. (1987). Toxicology of Fenvalerate and its constituents Isomers to the fathead minnow (Pimephales Promelos) and bluegill (Lepomis macrochirus). Bulletin of Environmental Contamination Toxicology, 38: 727-735.

Cabello, F.C. (2006). Heavy use of prophylactic antibiotics in aquaculture: a growing problem for human and animal health and for the environment. Environmental Microbiology, 8(7): 1137-1144.

Chor, W-K.; Lim, L.S. and Shapawi, R. (2013). Evaluation of feather meal as a dietary protein source for African catfish fry, Clarias gariepinus. Journal of Fisheries and Aquaculture Sciences, 8: 697-705.

Davies, S. J.; Williamson, J.; Robinson, M. and Bateson, R. (1991). Practical inclusion levels of common animal by-products in complete diets for tilapia (Oreochromis mossambicus, Peters). In: S.J. Kaushik, P. Luquet (Eds.), Fish Nutrition in Practice, INRA, Paris., 325-332.

Department of Water Affairs and Forestry, 1996. South African Water Quality Guidelines (second edition). Volume 6: Agricultural Water Use: Aquaculture.

Dohar, J.E. (2003). Evolution of management approaches for otitis externa. Pediatr Infect Dis J 22:299-308.

Doumas, B.T. (1975). Colorimetric determination of total protein in serum or plasma. Clin. Chem., 21 (8): 1159-1166.

Al-Harbi, A. H. and Uddin, M.N. (2010). Bacterial Populations of African Catfish, Clarias 
gariepinus (Burchell 1822) Cultured in Earthen Ponds', Journal of Applied Aquaculture, 22: 3, $187-193$.

El-Husseiny, O.M.; Abdul-Aziz, G.M.; El-Haroun, E. R. and Goda, A.M. (2006). Fish meal replacer studies with Nile tilapia and Mullet under polyculture conditions in Egypt. International Aquafeed, 9 (1): 20-29.

El-Sayed, Y.S. and Saad. T.T. (2007). Subacute Intoxication of a Deltamethrin-based Preparation (Butox® 5\% EC) in Monosex Nile Tilapia, Oreochromis niloticus L. Basic and Clinical Pharmacology, and Toxicology. 102: 293-299. Nordic Pharmacological Society.

Eyo, A.A. and Olatunde, A.A. (2000). Apparent protein digestibility and growth performance of Clarias anguillaris fingerlings fed isocaloric diets. Journal of Fish Technology 2: $30-42$.

FAO (2011). FAOSTAT. Food and Agriculture Organization of the United Nations.

Firat, O.; Cogun, H.Y.; Yüzereroğlu, T.A.; Gök, G.; Fırat, Ö.; Kargin, F. and Kötemen, Y.A. (2011). Comparative Study on the Effects of a Pesticide (Cypermethrin) and Two Metals (Copper, Lead) to Serum Biochemistry of Nile Tilapia, Oreochromis niloticus. Fish Physiology and Biochemistry, 37: 657-666.

Fossati, P. and Prencipe, L. (1982). Serum triglycerides determined colorimetrically with an enzyme that produces hydrogen peroxide. Clin. Chem. 28(10): 2077-2080.

GAFRD. (2015). Fish Statistics Year The general authority for fish resources development (GAFRD). pp 16.

Giri, S.S.; Sahoo, S. K.; Sahu, A.K. and Mukhopadhyay, P.K. (2000). Nutrient digestibility and intestinal enzyme activity of Clarias batrachus (Linn.) juveniles fed on dried fish and chicken viscera incorporated diets. Bioresource Technology. 71: 97-101.

Giri, S.S.; Sahoo, S.K. and Mohanty, S.N. (2010). Replacement of by-catch fishmeal with dried chicken viscera meal in extruded feeds: effect on growth, nutrient utilization and carcass composition of catfish Clarias batrachus (Linn.) fingerlings. Aquaculture International, 18: 539-544.

Goda, A.M.; El-Haroun, E.R. and Chowdhury, M.A. (2007). Effect of totally or partially replacing fish meal by alternative protein sources on growth of African catfish Clarias gariepinus (Burchell, 1822) reared in concrete tanks. Aquacult. Res., 38: 279-287.

Goddard, S. (1995). Feed Management in Intensive Aquaculture. Chapman and Hall, New York. p. 194.

Gupta, P.; Gupta, A. and Monica (2013). Effect of fish and chicken viscera incorporated diets on growth, feed utilization and body composition of Asian catfish, Clarias batrachus fry. Animal Nutrition and Feed Technology, 13: 195-203.

Hao, N. V. and Yu, Y. (2003). Partial replacement of fish meal by MBM and PFGPBM in diets for river catfish (Pangasianodon hypophthalmus). Research report No. 33.

Hasheesh, W.S.; Marie, M. A.; Abbas, H.H.; Eshak, M.G. and Zahran, E.A. (2011). An evaluation of the effect of $17 \alpha$-methyl testosterone hormone on some biochemical, molecular and histological changes in the liver of Nile tilapia; Oreochromis niloticus. Life Sci. J., 8: 343-358.

Hernandez, C.; Hardy, R.W.; Contreras-Rojas, D.; Lopez-Molina, B.; Gonzalez-Rodriguez, B. and Dominguez-Jimenez, P. (2014). Evaluation of Tuna by-product meal as a protein source in feed for juvenile spotted rose snapper Lutjanus guttatus. Aquaculture Nutrition, 20: 574-582.

Houlihan, D.; Bouiard, T. and Jobling, M. (2001). Food Intake in Fish. USA: Iowa State University Press. Blackwell Science Ltd., 418pp.

Hu, M.; Wang, Y.; Wang, Q.; Zhao, M.; Xiong, B.; Qian, X.; Zhao, Y. and Luo, Z. (2008). Replacement of fish meal by rendered animal protein ingredients with lysine and methionine supplementation to practical diets for Gibel carp, Carassus auratus gibelio, Aquaculture, 275: 260-265. 
Idodo-Umeh, G. (2005). The feeding ecology of Mochokid species in River Ase, Niger Delta, Nigeria. Tropical Freshwater Biology, 14: 71-93.

Jabir, M. D.; Jabir, S.A. and Vikineswary, S. (2012). Nutritive potential and utilization of super worm (Zophobas morio) meal in the diet of Nile tilapia (Oreochromis niloticus) juvenile. Afr. J. Biotechnol, 11(24): 6592-6598.

Jobling, M. (1995). Fish Bioenergetics, Chapman, and Hall, London. p. 309.

Kaplan, A.; Szabo, L.L. and Opheim, K.E. (1988). Clinical chemistry: Interpretation and techniques. 3rd edition. Philadelphia, USA, Lea, and Febiger.

Kefi, A.S.; Kang'ombe, J.; Kassam, D. and Katongo, C. (2013). Effect of $17 \alpha$ methyltestosterone on hematology and histology of liver and heart of Oreochromis andersonii (Castelnau, 1861). J. Mar. Sci. Res. Dev., 3(3): 130.

Khan, M.A. and Abidi, S.F. (2011). Dietary arginine requirement of Heteropneustes fossilis fry (Bloch) based on growth, nutrient retention and hematological parameters. Aquaculture Nutrition, 17: 418-428.

Levesque, R. (2007). SPSS Programming and Data Management, 4th Edition: A Guide for SPSS and SAS Users, SPSS Inc. Chicago, IL Pp 522.

Ma, X.; Wang, F.; Han. H.; Wang, Y. and Lin, Y. (2014). Replacement of Dietary Fish Meal with Poultry By-product Meal and Soybean Meal for Golden Pompano, Trachinotus ovatus, reared in Net Pens. Journal of the World Aquaculture Society, 45: (6) 662-671. MacFaddin, J. F. (1985). Media for Isolation, Cultivation, Identification, Maintenance of Bacteria", Vol. I. Williams \& Wilkins, Baltimore, MD.

Malla, R. P. and Bashamohiden, M.D. (1995). Alternation in protein metabolism in selected tissue of fish Cyprinus caprio during sublethal concentration of cypermethrin. Environ Monit Assess, 36: 183-190.

Massumotu, T.; Ruchmat, T. and Ito, Y. (1996). Amino acid availability value for several protein sources for yellowtail (Seriola quinqueradiate). Aquaculture, 146: 109-119.

Metwalli, A.A. (2008). Using of poultry by-product and hatchery by-product as partial replacement for fish meal in Nile tilapia (Oreochromis niloticus) diets. University of Sharjah Journal of Pure and Applied Sciences, 5 (2): 83-104.

M.A.L.R. (2015). Ministry of Agriculture and Land Reclamation (M.A.L.R). Economic Affairs Sector, Food Balance of Arab Republic of Egypt.

Moogouel, R.; Karbassi, A. R.; Monavari, S.M.; Rabani, M. and Taheri, M.A. (2010). Effect of the selected physico-chemical parameters on growth of rainbow trout (Oncorhynchus mykiss) in raceway system in Iran. Iranian J. Fisheries Sci., 9(2): 245254.

Musa, S. O. and Omoregie, E. (1999): Hematological changes in the mudfish, Clarias gariepinus (Burchell) exposed to malachite green. J. Aquat. Sci., 14: 37-42.

Nengas, I.; Alexis, M.N. and Davies, S.J. (1999). High inclusion levels of poultry meals and related by-products in diets for gilthead seabream (Sparus aurata L.). Aquaculture, 179: $13-23$

NRC. (2011). Nutrient Requirements of Fish and Shrimp. National Research Council of the National Academies, Washington D.C., 363 pp.

Nwani, C.D.; Ifo, C. T.; Nwamba, H. O.; Ejere, V.C.; Onyishi, G.; Ikwuagwu, E.O. and Odo, G.E. (2015). Oxidative stress and biochemical responses in the tissues of African catfish Clarias gariepinus juvenile following exposure to primextra herbicide. Drug Chem. Toxicol., 38(3): 278-285.

Nyina-wamwiza, L.; Wathelet, B. and Kestemont, P. (2007). Potential of local agricultural by-products for the rearing of African catfish Clarias gariepinus in Rwanda: effects on growth, feed utilization, and body composition. Aquaculture Research, 38: 206-214.

OATA. (2008). Ornamental Aquatic Trade Association Water Quality Criteria ornamental fish. Company Limited by Guarantee and Registered in England No 2738119 Registered Office Wessex House, 40 Station Road, Westbury, Wiltshire, BA13 3JN, 
UK.

Obomanu, F. G.; Gabrie, U. U.; Edori, O. S. and Emetonjor, J. N. (2009). Biomarker enzymes in muscle tissue and organs of Clarias gariepinus after intramuscular injection with aqueous extracts of Lepidagathis alopecuroides leaves. Journal of Medicinal Plants Research, 3(12): 995-1001.

Okan, A. and Gamsiza, K. (2010). Age and growth of adult gilthead seabream (Sparus aurata L.) in the Aegean Sea. Journal of the Marine Biological Association of the United Kingdom, 91: 1255-1259.

Oke, V.; Odountan, H.O. and Abou, Y. (2016). Chicken Viscera Meal as a Main Component in Diet for African Catfish Clarias gariepinus (Burchell 1822) Reared in Earthen Ponds. Journal of Food and Nutrition Research, 4(12): 799- 805

Okorie-Kanu, C.O. and Unakalamba, N.J. (2014a). Hematological and blood biochemistry values of cultured Heterobranchus longifilis in Umudike, Abia State, Nigeria. Anim Res Int 11: 1987-1993.

Okorie-Kanu, C.O. and Unakalamba, N.J. (2014b). Normal hematological and blood biochemistry values of cultured Heteroclarias hybrid in South East Nigeria. Comp. Clin. Pathol. 24(5): 1015-1020.

Olaniyi, C.O. and Salau, B.R. (2013). Utilization of maggot meal in the nutrition of African catfish. Afr. J. Agric. Res., 8(37): 4604-4607.

Olurin, K.B.; Olujo, A.A. and Olukoya, O.A. (2006). Growth of African Catfish Clarias gariepitus fingerlings, fed different levels of cassava. World J. Zool., 1: 54-56.

Omoruwou, P.E. and Edema, C.U. (2011). Growth response of Hetero-clarias hybrid fingerlings fed on maggot-based diet. Niger J. Agric Food Environ., 7(1): 58-62.

Öner, M.; Atli, G. and Canli, M. (2008). Changes in Serum Biochemical Parameters of Freshwater Fish Oreochromis niloticus Following Prolonged Metal (Ag, Cd, Cr, Cu, Zn) Exposure. Environmental Toxicology and Chemistry, 27: 360-366.

Orire, A.M. (2010). Protein Sparing Effects of Carbohydrate and Lipid in the Practical Diets of Catfish (Clarias gariepinus) and Tilapia (Oreochromis niloticus) Production. Ph.D. Thesis, Federal University of Technology, Minna, Nigeria.

Oyewole, I.O.; Momoh, O. O.; Anyasor, G. N.; Ogunnowo, A.A.; Ibidapo, C.A. and Oduola, O.A. (2008). Physico-chemical characteristics of Anopheles breeding site: impact on fecundity and progeny development, African Journal of Environmental Science and Technology., 3(12):447-452.

Paixao, A.M. and Filho, G.C. (1989). Residues of poultry incubators as a potential food for carp (Cyprinus carpio L.). Arq. Bras. Med. Vet. Zootec., 41 (4): 301-314.

Panteghini, M.; Pagani, F.; Bonora, R.; Alebardi, O. and Ceriotti, F. (1991). Diagnostic value of four assays for lipase determination in serum a comparative reevaluation. Clinical Biochemistry, 24(6): 497-504.

Patti, M. and Kulkarni, R. S. (1993). Ovarian and hepatic biochemical response to Sumaach (a crude form of HCG) in fish, Notopterus notopterus pallas, under pesticide treatment. Geobios, 20: 255-259.

Patton, C.J. and Crouh, S.R. (1977). Urea colorimetric endpoint determination ureaseBerthelot reaction. Annal. Chem., 49: 464-469.

Priestley, S.M.; Stevenson, E.S. and Alexander, L.G. (2006). The influence of feeding frequency on growth and body composition of the common goldfish (Carrassius auratus). J. Nutr., 136: 1979s-1981s.

PHE. (2014). Public Health England, Preparation of samples and dilutions, plating and subculture. Microbiol. Services, Food, Water \& Environ. Microbiol. Standard Method FNES26 (F2); Version 1.

Rauha, J. P; Remes, S.; Heinonen, M.; Hopia, A.; Kahk“onen, M.; Kujala, T.; Pihlaja, K.; Vuorela, H. and Vuorela, P. (2000). Antimicrobial effect to Finfish plant extracts containing flavonoids and other phenolic compounds. Intl J Food Microbiol, 56:3-12. 
Rawles, S.D.; Gaylord, T. G.; Matthew, E.M.; Freeman; D.W. (2009). Evaluation of Poultry By-product Meal in Commercial Diets for Hybrid Striped Bass, Morone chrysops $\times$ Morone saxatilis, in Pond Production. Journal of the World Aquaculture Society, 40(2): 141-156.

Rawles, S.D.; Riche, M.; Gaylord, T.G.; Webb, J.; Freeman, D.W. and Davis, M. (2006). Evaluation of poultry by-product meal in commercial diets for hybrid striped bass (Morone chrysops $+\times$ Morone saxatilis $ठ^{\Uparrow}$ ) in recirculated tank production. Aquaculture, 259: 377-389.

Reverter, M.; Bontemps, N.; Lecchini, D.; Banaigs, B. and Sasal, P. (2014). Use of plant extracts in fish aquaculture as an alternative to chemotherapy: Current statue and future perspectives. Aquaculture, 433: 50-61.

Romero, J.; Carmen, G.F. and Paola, N. (2012). Antibiotics in Aquaculture; Use, Abuse, and Alternatives. Health and Environment in Aquaculture. Edited by Dr. Edmir Carvalho, Publisher InTech, 159-198.

Rutala, W.A.; Barbee, S. L.; Agular, N.C.; Sobsey, M. D. and Weber, D.J. (2000). Antimicrobial activity of home disinfectants and natural products against potential human pathogens. Infect Control Hosp Epidemiol, 21:33-8.

Santhosh, B. and Singh, N.P. (2007), Guidelines for water quality management for fish culture in Tripura, ICAR Research Complex for NEH Region, Tripura Center, Publication no. 29.

Sawhney, S. and Gandotra, R. (2010). Growth Response and Feed Conversion Efficiency of Tor putitora (Ham.) Fry at Varying Dietary Protein Levels. Pakistan Journal of Nutrition, 9 (1): 86-90.

Seith, N. and Saxena, K.K. (2003). Hematological responses in a freshwater fish, Channa punctatus due to fenvalerate. Bull Environ Cont Toxicol., 71: 1192-1199.

Sogbesan, O.A.; Ajuonu, N.; Musa, B.O. and Adewole, A.M. (2006). Harvesting techniques and evaluation of maggot meal as animal dietary protein source "Heteroclarias" in outdoor concrete tanks. World J Agric Sci., 2(4): 394-402.

Srour, T. M.; Essa, M. A.; Abdel-Rahim, M. M. and Mansour, M. A. (2016) Replacement of Fish Meal with Poultry By-product Meal (PBM) and its effects on the Survival, Growth, Feed Utilization, and Microbial Load of European Seabass, Dicentrarchus labrax fry. Global Advanced Research Journal of Agricultural Science (GARJAS); 5 (7): 293-301, ISSN - 2315-5094.

Sugumaran, E. and Radhakrishnan, M.V. (2015). Feed utilization, growth and carcass composition of catfish Clarias batrachus (L.) fed on fish meal replaced by dried chicken viscera incorporated diets. International Journal of Research in Fisheries and Aquaculture, 5: 143-146.

Sun, C.X.; Xu, W.N.; Li, X.F.; Zhang, D.D.; Jiang, G.Z. and Liu, W.B. (2014). Effect of fish meal replacement with animal protein blend on growth performance, nutrient digestibility and body composition of juvenile Chinese soft-shelled turtle Pelodiscus sinensis. Aquaculture Nutrition, 1-11.

Tabinda, A.B. and Butt, A. (2012). Replacement of fish meal with poultry by-product meal (chicken intestine) as a protein source in grass carp fry diet. Pakistan J. Zool., 44(5): 1373-1381.

Tabinda, A.B.; Ghazala, R.; Yassar, A. and Ashraf, M. (2013). Utilization of chicken intestine as an alternative protein source in the diet for fingerlings of Cirrhinus mirigala. The Journal of Animal and Plant Sciences, 23: 1603-1608.

Turker, A.; Murat, Y.; Sebahattin, E.; Burcu, K. and Erteken, A. (2005). Potential of Poultry By-Product Meal as a substitute for fish meal in diets for Black Seabass Turbot Scophthalmus maeoticus: Growth and Nutrient Utilization in winter. The Israeli Journal of Aquaculture - Bamidgeh, 57(1): 49-61.

Winn-Deen, E.S.; David, H.; Sigler, E. and Chavez, R. (1988). Development of a Direct 
Assay for $\alpha$-Amylase, Clin. Chem. 34/10, 2005-2008.

Wuraola1, O.B. and Omodara, G.K. (2014). Effect of feeding frequency on the growth and feed utilization of catfish hybrid (Heterobranchus bidorsalis $\mathrm{X}$ Clarias gariepinus) fingerlings. Journal of Agriculture and Environmental Sciences., 3(3): 9-16.

Yadav, R. P.; Singh, D.; Singh, S. K. and Singh, A. (2003). Metabolic Changes in Freshwater fish Channa punctatus due to stem-bark extract of Croton tiglium. Pakistan J. Biolog. Sci., 6: 1223-1228.

Yamamoto, T.; Shima, T.; Furuita, H. and Suzuki, N. (2002). Influence of feeding diets with and without fish meal by hand and by self-feeders on feed intake, growth and nutrient utilization of juvenile rainbow trout (Oncorhynchus mykiss). Aquacult., 214: 289-305.

Yang, Y.; Xie, S.; Cui, Y.; Zhu, X.; Lei, W. and Yang, Y. (2006). Partial and total replacement of fishmeal with poultry by-product meal in diets for gibel carp, Carassius auratus gibelio Bloch. Aquaculture Research, 37: 40-48.

Yigit, M.; Erdem, M.; Koshio, S.; Ergun, S.; Turker, A. and Karaali, B. (2006). Substituting fish meal with poultry by-product meal in diets for black sea turbot Psetta maeotica. Aquaculture Nutrition, 12: 340-347.

Yones, A.M. and Metwalli, A.A. (2016). Effects of fish meal substitution with poultry byproduct meal on growth performance, nutrients utilization and blood contents of juvenile Nile tilapia (Oreochromis niloticus). J. Aquac. Res. Development, 7: 389.

\section{ARABIC SUMMARY}

هل تغذية أسماك القرموط الافريقي (Clarias gariepinus) على أحشاء الدواجن المفمورة فى الخل تؤُثر علي

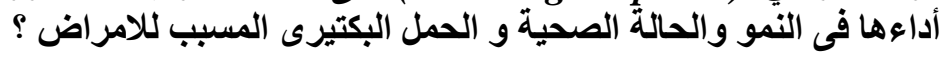

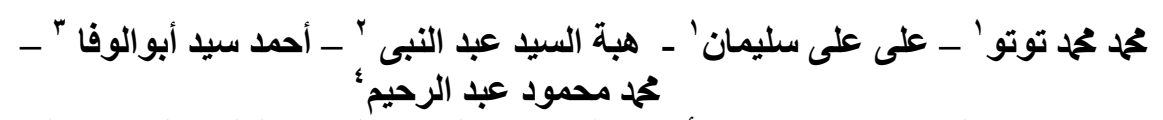

1. معمل تغذية الاسماك ـ شعبة تربية الأحياء المائية ـ المعهد القومى لعلوم البحار و المصايد ،

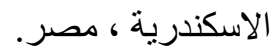

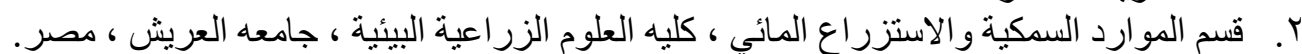

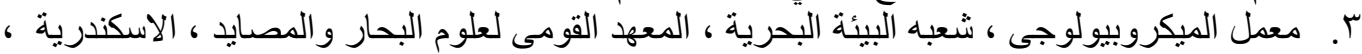

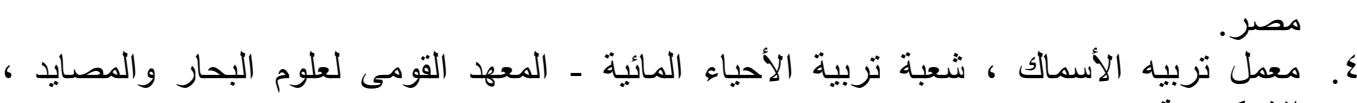
الاسكندرية ، مصري تربه الاصمر.

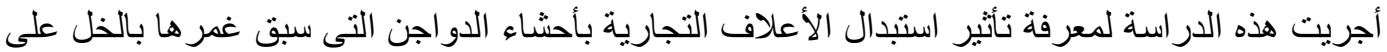

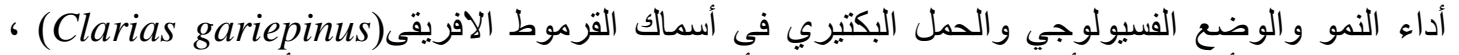

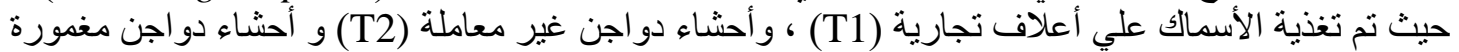

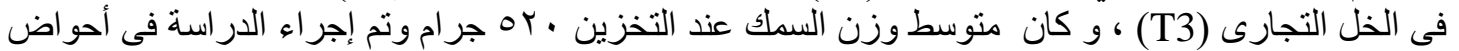

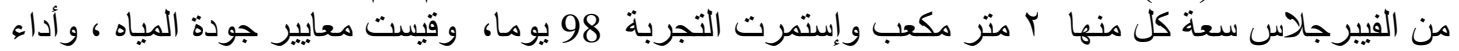

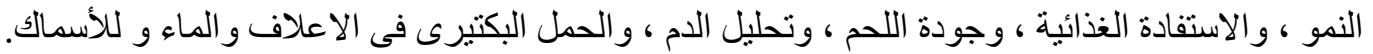

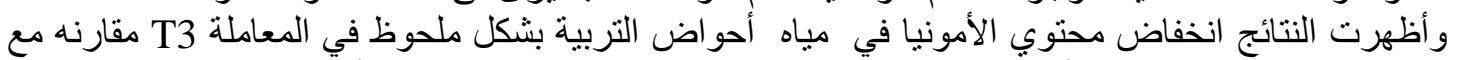

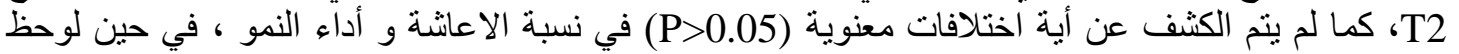

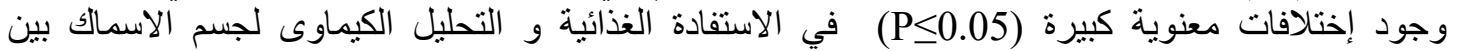

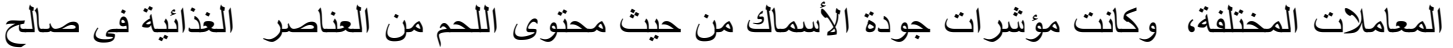

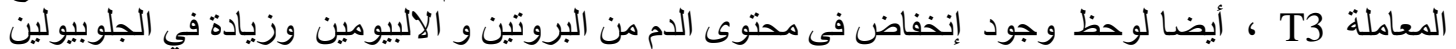

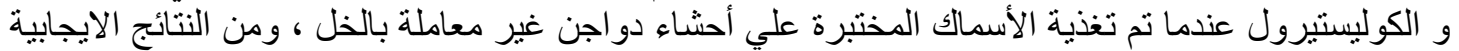

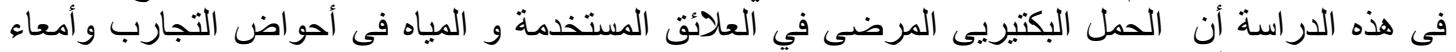

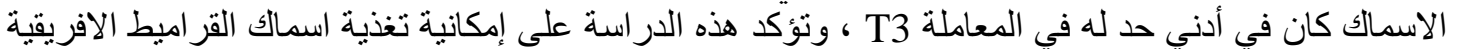

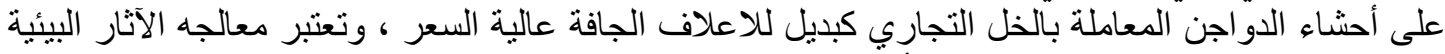

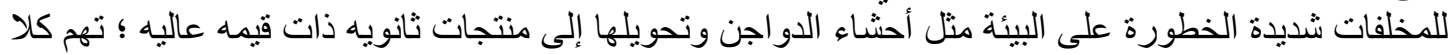

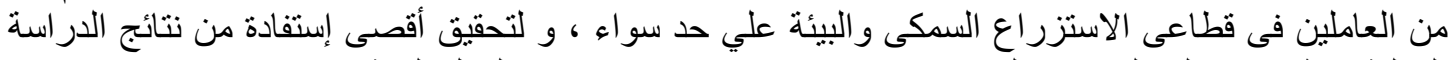

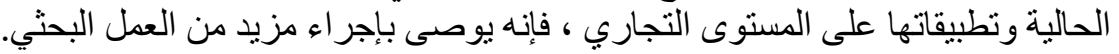

